\title{
INTRAMUSCULAR LIPOMA OF THE LOWER LIMB
}

\author{
LONG-TERM FOLLOW-UP AFTER LOCAL RESECTION
}

PER BJERREGAARD, KIKKE HAGEN, SØREN DAUGAARD, HAKON KOFOED

From the Rigshospital, Copenhagen

We report 12 patients with infiltrating muscular lipomas of the lower limbs all treated by wide resection. During follow-up averaging seven years, the tumour recurred in five patients. Our results and those reported by others suggest that, in order to avoid recurrence, this tumour, although benign, should be treated by total excision of the muscle or by compartmental resection. Hormonal imbalance was suspected in 9 of the patients but an oestrogen receptor analysis of the histological samples proved negative.

An intramuscular, or infiltrating, lipoma is a benign tumour, but its deep location simulates that of a soft tissue sarcoma and its unencapsulated growth pattern impedes effective surgical treatment. Reported recurrence rates vary from 0 to $80 \%$ (Dionne and Seemayer 1974; Austin et al 1980). The obscure pathogenesis of the lipoma led us to search for other clinical signs, and the unsatisfactory recurrence rate led to a re-evaluation of the methods of treatment.

\section{PATIENTS AND METHODS}

From 1971 to 198112 patients (nine women and three men) with a mean age of 52 years (range 26 to 72) presented with soft tissue tumours in which the histopathological diagnosis was intramuscular lipoma. Before operation soft tissue radiographs were taken of 10 patients, CT scans of four and angiographs of four. Excisional biopsy was performed in all cases, three before and nine during resection. Once malignancy had been excluded, the tumours were removed by local resection with a margin of macroscopically healthy muscle.

Postoperatively we continued to review eight patients and the remaining four were seen at other hospitals.

P. Bjerregaard, MD, Orthopaedic Registrar

K. Hagen, MD. Orthopaedic Registrar

S. Daugaard, MD, Registrar in Pathology

H. Kofoed, MD, MS Orth, Orthopaedic Surgeon

Rigshospital, University of Copenhagen, DK-2100, Denmark.

Correspondence should be sent to Dr P. Bjerregaard at Jaegerparken 9. st.th., DK 2970 Hørsholm. Denmark.

(C) 1989 British Editorial Society of Bone and Joint Surgery $0301-620 X / 89 / 5159 \$ 2.00$

J Bone Joint Surg [Br] 1989:71-B:812-5.
The mean follow-up was 7.3 years (range 5.3 to 15.8). No patient died during this period.

For our study, patients' clinical records were reviewed with emphasis on symptoms, size and site of tumours, diagnostic procedures, surgical treatment and recurrence, if any. The histological specimens were reviewed blind by one author(SD), looking for diagnostic infiltration of skeletal muscle tissue, vascularity, necrosis, fibrosis and signs of malignancy. As seven of the women had received hormonal treatment, one man had gynaecomastia and another had testicular atrophy, new sections were made from the old paraffin blocks from all 12

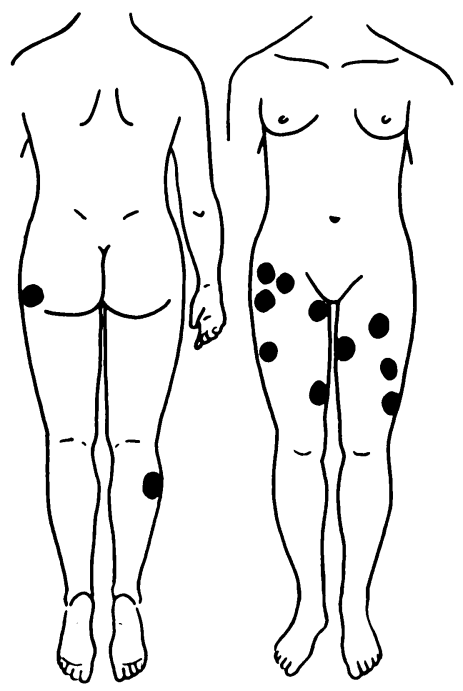

Fig. 1

Location of primary infiltrating lipomas 
patients and tested immunohistochemically for the presence of oestrogen receptors. Finally, 10 of the patients were examined for clinical signs of recurrence and any operative complications such as sensory or motor dysfunction. Two patients had only interviews as they had recently had a routine review.

\section{RESULTS}

The size and duration of symptoms of each tumour are listed in Table I, and the sites are shown in Figure 1.

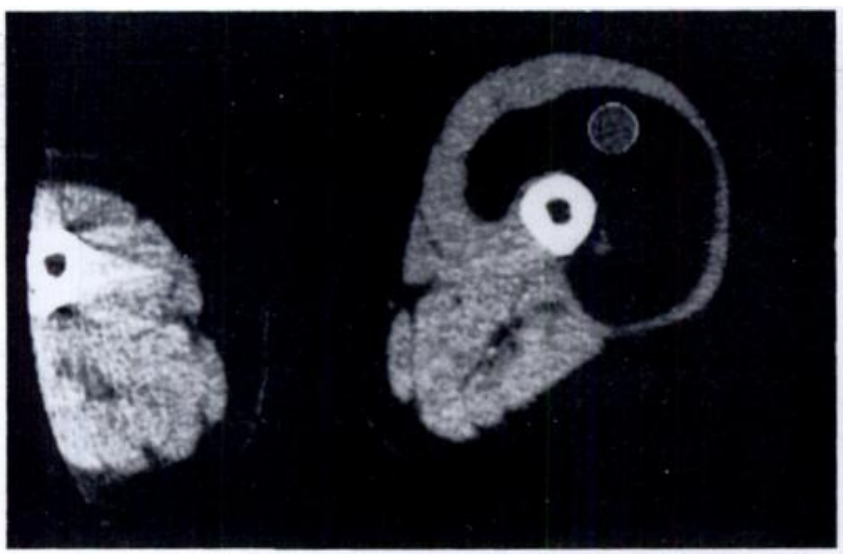

Fig. 2a

CT scan showing a homogenous intramuscular lipoma which is well delineated and has a negative attenuation value of -50

Table I. Size and duration of symptoms of infiltrating lipomas in 12 patients at the time of operation

\begin{tabular}{lllc}
\hline Case & $\begin{array}{l}\text { Age } \\
\text { (years) }\end{array}$ & $\begin{array}{l}\text { Size } \\
\text { (cm) }\end{array}$ & $\begin{array}{l}\text { Duration of } \\
\text { symptoms } \\
\text { (months) }\end{array}$ \\
\hline 1 & 26 & $11 \times 9 \times 6$ & 1 \\
2 & $51+$ & $11 \times 9 \times 6$ & 3 \\
3 & 34 & $9 \times 6 \times 6$ & $<1$ \\
4 & 52 & $15 \times 10 \times 10$ & 2 \\
5 & 47 & $10 \times 10 \times 7$ & $>24$ \\
6 & 53 & $2 \times 2 \times 2$ & 4 \\
7 & 72 & $16 \times 7 \times 7$ & 2 \\
8 & 46 & $4 \times 4 \times 1$ & 2 \\
9 & 71 & $14 \times 12 \times 10$ & 13 \\
10 & $54+$ & $24 \times 11 \times 3$ & 4 \\
11 & 62 & $25 \times 10 \times 5$ & $<1$ \\
12 & $47 \dagger$ & $15 \times 9 \times 6$ & 36 \\
Median & 52 & $12.5 *$ & 3 \\
Range & 26 to 72 & 2 to $25 *$ & $<1$ to 36 \\
\hline
\end{tabular}

* longest diameter

+ male
The main pre-operative complaint had been a steadily enlarging local swelling. Other symptoms, if any, were mild and usually only a feeling of local tightness or dull pain. Only one patient had moderate pain which inhibited normal function of his leg.

The CT scans of three tumours showed homogeneity, good delineation and negative attenuation values near adjacent normal adipose tissue (Fig. 2a), but one showed lack of homogeneity with positive attenuation values (Fig. 2b). In this tumour histology revealed areas of necrosis, haemorrhage and cyst formation.

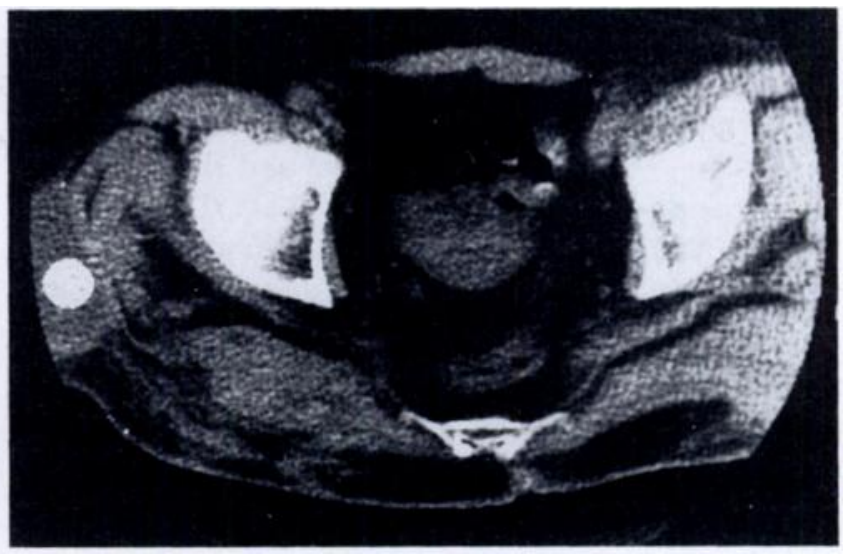

Fig. 2b

CT scan of an intramuscular lipoma with necrosis and haemorrhage. It is poorly delineated and its attenuation value is +11 .

Histological re-examination showed, in all cases, well differentiated adipose tissue, which in some areas contained widely separated, but often normal or slightly atrophic muscle fibres. None showed any signs of malignancy. Vascularity was moderate and in no case was the diagnosis of angiolipoma justified, all sections confirming the original diagnosis of intramuscular lipoma. All tests for oestrogenic receptors were negative.

Five patients had suffered recurrence after a median period of 86.5 months (range 63 to 188), one on two occasions (Table II). All recurrences were at the site of the primary lesion, appearing at a median time of 49.5 months (range 8 to 94 ), with a median longest diameter of $13.5 \mathrm{~cm}$ (range 2 to 30). Pre-operative and postoperative complaints and disabilities are compared in Table III.

\section{DISCUSSION}

Since the clinical signs of an intramuscular lipoma are identical to those of a liposarcoma (Rydholm and Berg 1983), management should be that of liposarcoma until the diagnosis is certain.

Because of uncertainty about the population at risk we cannot give an accurate incidence from our series. 
According to Austin et al (1980), infiltrating lipomas are rare, but although this type constitutes under $1 \%$ of all lipomas (Myhre-Jensen 1981), it may still be the most common deep-seated soft tissue tumour (Kindblom et al 1974). Large dimensions at diagnosis (over $5 \mathrm{~cm}$ ), a deep subfascial location and a predilection for the large muscle groups of shoulder, upper arm, hip and thigh are the main clinical features (Kindblom et al 1974; Enzinger and Weiss 1983). These features all justify a suspicion of malignancy (Rydholm and Berg 1983), so patients who present with such tumours are often referred to a tumour centre.

In our series, the tumour was generally soft in consistency, hardening with contraction of the muscle group involved. Pain and tenderness were usually absent, but pressure-induced sensory and vascular disturbances have been reported (Regan, Bickel and Broders 1946; Dionne and Seemayer 1974; Austin et al 1980). CT scans help to determine the location of the tumour and may reveal invasion of adjacent structures (Halldorsdottir, Ekelund and Rydholm 1982). An infiltrating lipoma usually gives negative attenuation values, good delineation and absence of contrast enhancement (Halldorsdottir et al 1982), but degeneration, haemorrhage and necrosis within the tumour may blur the picture, and we feel that biopsy is essential. It may be that magnetic resonance imaging will provide more accurate information than CT scanning (Pettersson et al 1985).

Infiltrating lipomas tend to recur (Enzinger and Weiss 1983); only compartmental resection will prevent this completely. We treated our patients by local resection into healthy muscle, with due regard to structures vital to the function of the limb (Dionne and Seemayer 1974). In Table IV we show documented series of completely excised infiltrating lipomas with an observation period of over six months. The mean rate of recurrence is about $50 \%$, matching our findings. Kindblom et al (1974) reported no recurrence in 33 patients who had complete muscle excision, but local resection is a less major procedure, producing much less discomfort and disability.
Table II. Total follow-up, timing and size of recurrence

\begin{tabular}{llll}
\hline Case & $\begin{array}{l}\text { Total follow-up } \\
\text { observation } \\
\text { (months) }\end{array}$ & $\begin{array}{l}\text { Recurrence } \\
\text { (months) }\end{array}$ & $\begin{array}{l}\text { Size of } \\
\text { recurrence } \\
\text { (cm) }\end{array}$ \\
\hline 1 & 188 & - & - \\
2 & 136 & - & - \\
3 & 127 & $33+51$ & $7 \times 5 \times 3$ \\
4 & 116 & - & $15 \times 9 \times 10$ \\
5 & 115 & - & - \\
6 & 94 & 94 & $2 \times 2 \times 2$ \\
7 & 79 & 48 & $12 \times 8 \times 8$ \\
8 & 78 & - & - \\
9 & 76 & 74 & $15 \times 10 \times 5$ \\
10 & 68 & 8 & $30 \times 25 \times 5$ \\
11 & 64 & - & - \\
12 & 63 & - & - \\
\hline Median & 86.5 & 49.5 & 13.5 \\
Range & 63 to 188 & 8 to 94 & 2 to 30 \\
\hline & & & \\
\hline
\end{tabular}

Table III. Symptoms reported before (B) and/or after (A) operation for infiltrating lipoma

\begin{tabular}{lllll}
\hline Case & Tightness & $\begin{array}{l}\text { Pain or } \\
\text { tenderness }\end{array}$ & $\begin{array}{l}\text { Hypoaesthesia } \\
\text { or paraesthesia }\end{array}$ & $\begin{array}{l}\text { Impaired } \\
\text { gait }\end{array}$ \\
\hline 1 & B & A & & \\
4 & B & A & A & A \\
6 & B & & & \\
7 & & B & \\
8 & B & B & & \\
11 & & BA & A & \\
12 & & & A \\
\hline
\end{tabular}

Table IV. Reports of treatment and results in well-documented series followed up for over six months

\begin{tabular}{lclll}
\hline Authors & Patients & Operation & Recurrence & $\begin{array}{l}\text { Observation } \\
\text { time (years) }\end{array}$ \\
\hline Regan et al 1946 & 2 & Local excision & 1 & 1 to 4 \\
Wurlitzer et al 1973 & 1 & $\begin{array}{l}\text { Local excision } \\
\text { Radical excision }\end{array}$ & 0 & 1 \\
Kindblom et al 1974 & 1 & $\begin{array}{l}\text { Myectomy or wide } \\
\text { excision }\end{array}$ & 0 & 2 \\
Dionne and Seemayer 1974 & 6 & Local excision & 4 & 0.5 to 20 \\
Austin et al 1980 & 3 & Local excision & 0 & 1 to 3 \\
Bjerregaard et al 1989 & 12 & Local excision & 5 & 5 to 15 \\
\hline
\end{tabular}


However, frequent recurrences are very worrying for the patient, so muscle excision, still avoiding vital structures, may prove to be preferable.

Our histological results did not differ from those described previously (Dionne and Seemayer 1974; Kindblom et al 1974), but diagnosis needs confirmation by representative excisional biopsy. Fine needle aspiration cytology has been proposed (Rydholm et al 1982); it may suffice in establishing malignancy, but because of the lack of homogeneity of liposarcomata, which may contain areas of normal adipose tissue, we do not regard this technique as entirely reliable.

The pathogenesis of infiltrating lipoma remains obscure, and we could not establish any association with trauma or any other factor. The fact that nine of our 12 patients had some hormonal imbalance may indicate that endocrine disturbances may have a role, but we found, as in normal adipose tissue, no evidence of oestrogenic receptors. Other steroid receptors may be involved, or, as in simple lipomas (Mitelman 1988), a chromosomal disorder might be a factor. Unfortunately, our retrospective study did not include chromosome analysis.

Conclusions. Pre-operative CT scans are useful in determining the size and distribution of intramuscular lipomas, but the diagnosis must be confirmed by excisional biopsy. Because of the frequent recurrences after local resection we recommend consideration of total resection of involved muscles.

No benefits in any form have been received or will be received from a commercial party related directly or indirectly to the subject of this article.

\section{REFERENCES}

Austin RM, Mack GR, Townsend CM, Lack EE. Infiltrating (intramuscular) lipomas and angiolipomas: a clinicopathologic study of six cases. Arch Surg 1980:115:281-4.

Dionne GP, Seemayer TA. Infiltrating lipomas and angiolipomas revisited. Cancer 1974;33:732-8.

Enzinger FM, Weiss SW. Soft tissue tumors. St Louis, etc: CV Mosby Company, 1983.

Halldorsdottir A, Ekelund L, Rydholm A. CT-diagnosis of lipomatous tumors of the soft tissues. Arch Orthop Trauma Surg 1982;100: 211-6.

Kindblom LG, Angervall L, Stener B, et al. Intermuscular and intramuscular lipomas and hibernomas: a clinical, roentgenologic, histologic, and prognostic study of 46 cases. Cancer 1974;33: 754-62.

Mitelman F. Catalog of chromosome aberrations in cancer. 3rd ed. New York: Alan R. Liss, 1988.
Myhre-Jensen O. A consecutive 7-year series of 1331 benign soft tissue tumours: Clinicopathologic data. Comparison with sarcomas. Acta Orthop Scand 1981;52:287-93

Pettersson H, Hamlin DJ, Mancuso A, Scott KN. Magnetic resonance imaging of the musculoskeletal system. Acta Radiol [Diagn] (Stockh) 1985;26:225-34.

Regan JM, Bickel WH, Broders AC. Infiltrating benign lipomas of the extremities. West J Surg 1946;54:87-93.

Rydholm A, Akerman M, Idvall I, Persson BM. Aspiration cytology of soft tissue tumours: a prospective study of its influence on choice of surgical procedure. Int Orthop 1982;6:209-14.

Rydholm A, Berg NO. Size, site and clinical incidence of lipoma : factors in the differential diagnosis of lipoma and sarcoma. Acta Orthop Scand 1983;54:929-34

Wurlitzer F, Bedrossian C, Ayala A, et al. Problems of diagnosing and treating infiltrating lipomas. Am Surg 1973;39:240-3. 